О. М. Утевская ${ }^{1}$, к.б.н., доцент

М. И. Чухряева ${ }^{2}$, научный сотрудник

P. А. Схаляхо ${ }^{2}$, к.б.н., старший научный сотрудник

Х. Д. Дибирова ${ }^{2}$, к.б.н., ведущий научный сотрудник

И. Э. Теучеж ${ }^{2}$, к.б.н., научный сотрудник

А. Т. Агджоян ${ }^{3}$, научный сотрудник

Л. А. Атраментова ${ }^{1}$, д.б.н., профессор

Е. В. Балановская ${ }^{2}$, д.б.н., зав. лаб.

О. П. Балановский ${ }^{3}$, д.б.н., зав. лаб.

${ }^{1}$ Харьковский национальный университет имени В. Н. Каразина, пл. Свободы, 4, Харьков, 61022, Украина, e-mail: outevsk@yandex.ua

${ }^{2}$ ФГБНУ «Медико-генетический научный центр», ул. Москворечье, 1, Москва, 115478, Россия

${ }^{3}$ Институт общей генетики им. Н. И. Вавилова РАН, ул. Губкина, 3, Москва, 119991, ГСП-1, Россия

\title{
ПРОИСХОЖДЕНИЕ ОСНОВНЫХ ГРУПП КАЗАЧЕСТВА ПО ДАННЫМ О ПОЛИМОРФИЗМЕ Ү-ХРОМОСОМЫ
}

\begin{abstract}
Основные группы казачества изучены по SNP-маркёрам Y-хромосомы. Кубанские, донские и запорожские казаки образуют единый фрагмент восточнославянского генофонда. Отсутствие или низкие частоты восточноевразийских и кавказских Y-хромосомных гаплогрупп $\mathrm{C}, \mathrm{O}, \mathrm{G}$ и J отклоняют гипотезу об участии кавказского и азиатского населения в генезе этих групп украинского и южнорусского казачеств. Генофонд терских казаков включает компоненты коренных народов Кавказа.
\end{abstract}

Ключевые слова: казаки; SNP-маркёры; Y-хромосома; гаплогруппы; генетическое расстояние.

На юге Восточной Европы сформировалось несколько групп казачества, наиболее крупными из которых являются запорожские, донские, кубанские и терские казаки. Обычно казаки, имеющие множество этнографических особенностей, рассматриваются как субэтнические группы русских или украинцев. Однако, с точки зрения популяционной генетики, до сих пор не ясно, действительно ли казаки представляют отдельные субэтнические группы, или же это «конгломератные» группы, объединённые родом деятельности.

Первоначально казаки были русскими или украинскими переселенцами, занимающими свободные земли в приграничных степных районах во времена поздней славянской экспансии в Восточной Европе. Казаки соседствовали с местными тюркоязычными группами, и ряд историков предполагает существование между ними настолько интенсивных контактов, что в итоге в их генофонд было включено больше тюркского компонента, чем славянского. 
Иногда казаки рассматриваются как непосредственные потомки неславянских племён, таких как хазары или черкесы. Современные казаки выделяют себя на фоне окружающего населения и нередко являются в той или иной степени эндогамными группами.

Целью данной работы было выявление генетических особенностей различных групп казачества. Это позволило оценить как степень сходства всех популяций казаков друг с другом, с украинцами и русскими, так и рассмотреть теории включения в состав казачества значительных неславянских компонентов от вливавшегося в их состав населения степей. Ключевым моментом являлось использование маркёров нерекомбинирующей части Ү-хромосомы, позволяющих прослеживать отцовские линии в эволюции генофонда $[6,11]$. Y-хромосомный полиморфизм восточных славян $[2,3,5,12]$, народов Кавказа $[1,4,9]$, тюрков Евразии $[4,10]$ и других европейских народов уже исследован на высоком уровне, что даёт качественный материал для сравнения.

\section{Материалы и методы исследования}

Материалом для исследования были образцы ДНК четырёх казачьих групп (табл. 1.) Донорами биологических образцов были неродственные друг другу мужчины, предки которых до третьего поколения относились к соответствующей казачьей группе и проживали в данном районе. Участие в исследовании было добровольным. Каждый донор подписал информированное согласие на проведение исследования.

Таблица 1

Локализация исследованных популяций

\begin{tabular}{|l|c|l|}
\hline \multicolumn{1}{|c|}{ Популяция } & $\begin{array}{c}\text { Объём вы- } \\
\text { борки }\end{array}$ & \multicolumn{1}{|c|}{ Локализация выборок } \\
\hline $\begin{array}{l}\text { Донские казаки } \\
\text { (нижние) }\end{array}$ & 151 & $\begin{array}{l}\text { Россия, Ростовская область, Константиновский и Усть- } \\
\text { Донецкий районы }\end{array}$ \\
\hline $\begin{array}{l}\text { Донские казаки } \\
\text { (верхние) }\end{array}$ & 162 & $\begin{array}{l}\text { Россия, Ростовская область, Шолоховский, Боковский и } \\
\text { Верхнедонской районы }\end{array}$ \\
\hline Кубанские казаки & 100 & Россия, Республика Адыгея, Майкопский район \\
\hline Терские казаки & 133 & $\begin{array}{l}\text { Россия, Кабардино-Балкария, Майский и Прохладненский } \\
\text { районы }\end{array}$ \\
\hline Запорожские казаки & 88 & $\begin{array}{l}\text { Украина, Запорожская область, г. Запорожье, Бердянский } \\
\text { район }\end{array}$ \\
\hline
\end{tabular}

Выделение ДНК из донорской крови проводилось методом фенол-хлороформной экстракции. Генотипирование образцов по SNP-маркёрам (Single Nucleotide Polymorphism - однонуклеотидный полиморфизм) Y-хромосомы проводилось методом ПЦР в реальном времени (7900HT, Applied Biosystems) 
с набором TaqMan зондов на 33 SNP-маркёра Y-хромосомы (Applied Biosystems): M198, P37.2, M458, M269, M78, M253, M178, M217, M33, M2, M35, M201, M285, P15, P16, P18, M406, P303, M69, M170, M223, M267, P58, M172, M67, M92, M12, P43, M242, M207, M173, M297, M70. Каждому маркёру согласно классификации Международного Консорциума по Ү-хромосоме [13], соответствует определённая гаплогруппа Y-хромосомы. Классификация гаплогрупп Y хромосомы и их соответствие маркёрам приведены согласно ISOGG [www.isogg.org].

По итогам генотипирования для каждой популяции были рассчитаны частоты гаплогрупп Ү-хромосомы. По частотам гаплогрупп рассчитаны генетические расстояния $d$ между популяциями [8]:

$$
d_{\dot{\jmath}}=-\mathrm{h} \frac{\sum_{a=1}^{l} p_{\dot{a}} \cdot p_{\dot{\jmath}}}{\sqrt{\sum_{a=1}^{l} p_{i}^{2} \sum_{a=1}^{l} p_{j}^{2}}},
$$

где $p_{a i}$ - частота гаплогруппы $a$ в популяции $i, p_{a j}$ - частота гаплогруппы $a$ в популяции $j, l$ - общее число гаплогрупп, по которым проводится сравнение.

Расчёт генетических расстояний проводился в программе GDist, разработанной в лаборатории популяционной генетики человека Медико-Генетического Центра РАМН. Чтобы рассматривать казачьи группы на общем фоне генетической изменчивости Восточной Европы, все расчёты проводились в более широком масштабе, включающем Украину, юг и центр России, Польшу, Беларусь, Прибалтику, страны Балканского полуострова, Кавказ, народы Поволжья, центральную Европу. Для этого использована информация из базы данных Y-base, разработанной в ФГБУ «МГНЦ» РАМН. Для расчёта генетических расстояний использованы частоты следующих гаплогрупп: E1b (M35), G (M201), I1 (M253), I2a (P37.2), J (M304), N1c (M178), R1b (M269), другие суммарно. Полученные матрицы генетических расстояний были проанализированы методами многомерного шкалирования с использованием пакета программ STATISTICA 8.0. Генетические расстояния использованы также для построения соответствующих карт в программе GeneGeo [7]. Карты построены на основании генетических расстояний, рассчитанных от реперных популяций до более чем двухсот популяций Европы, Урала, Кавказа и Ближнего Востока.

\section{Результаты и обсуждение}

В большинстве казачьих групп - у донских, кубанских и запорожских казаков - основными гаплогруппами являются R1a1a1*(M198), I2a (P37.2), R1a1a1g (M458), N1c1 (M178), I1 (М253) и R1b1b2 (М269), которые встречались с частотой не менее $5 \%$ и совместно составляли около $90 \%$ генофонда (рис. 1). На долю остальных гаплогрупп - С3 (M217), E1a (M33), E1b1a1 (M2), E1b1b1* (M35), E1b1b1a1 (M78), G* (M201), G1 (M285), G2a* (P15), 
G2a1a (P18), G2a3a (M406), G2a3b1 (P303), H (M69), I* (M170), I2a2a (M223), J1* (M267), J1c3 (P58), J2* (M172), J2a3b* (M67), J2a3b1 (M92), J2b (M12), N1b (P43), Q (M242), R* (M207), R1* (M173), R1b1a* (M297), T1 (M70) - суммарно приходилось менее $10 \%$. Такой спектр и частоты гаплогрупп в целом характерны для восточных славян, определяющих генетический ландшафт юга Восточной Европы [5].

Примечательно, что «восточно-евразийские» гаплогруппы С (M130) и O (М175), широко распространённые в азиатских степях, практически отсутствуют в перечисленных казачьих, равно как русских и украинских $[2,5$, 12], популяциях. «Кавказские» Y-хромосомные гаплогруппы G и J не были распространены среди исследованных потомков запорожских, донских и кубанских казаков, что не подтверждает гипотезу об активном участии кавказского населения в генезе украинского и южнорусского казачества. Частоты Y-хромосомных гаплогрупп в основных казачьих группах очень близки к аналогичным частотам в украинских и южнорусских популяциях, которые являются их географическими соседями.

Исключением были терские казаки, у которых частоты гаплогрупп R1a1a1*(M198) и I2a (P37), типичных для украинцев и русских $[2,5,12]$, были соответственно в полтора и два раза ниже, а частоты минорных для украинцев и русских гаплогрупп G2a3b1 (P303) и G2a1a (P18), распространённых на Ceверном Кавказе [9], были существенно повышены.

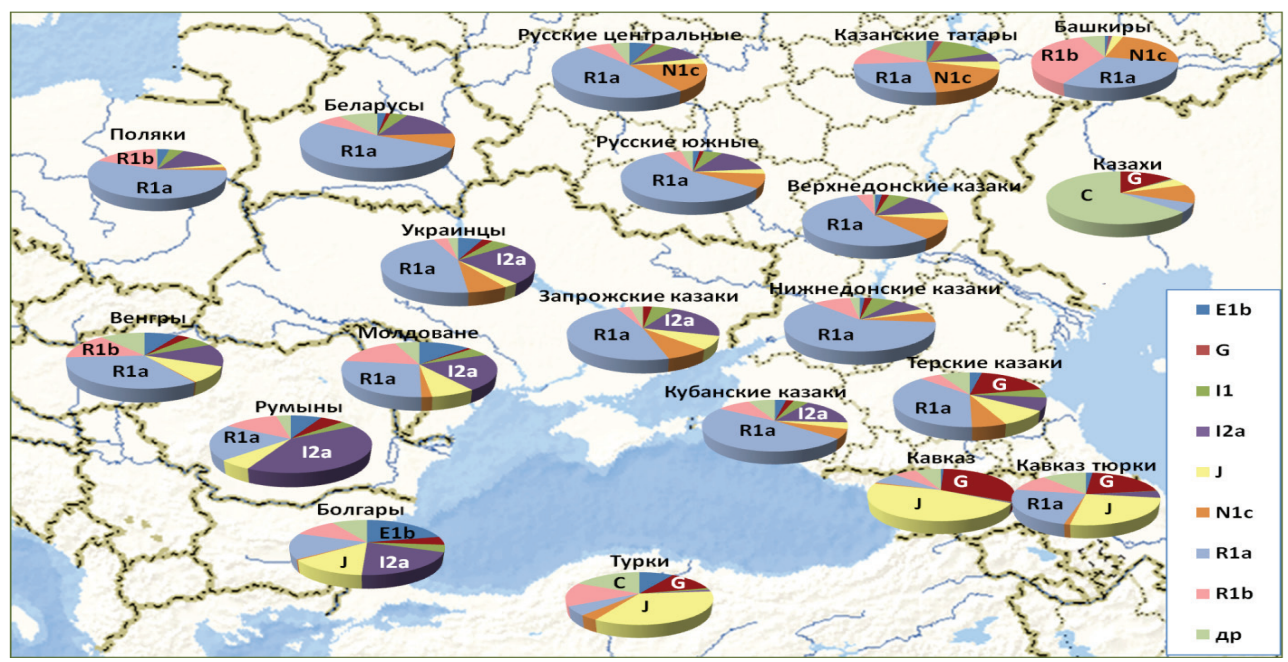

Рис. 1. Частотное распределение гаплогрупп Ү хромосомы в популяциях Восточной Европы

Для понимания места казачьих популяций на восточноевропейском генетическом ландшафте, восточноевропейские популяции были сгруппированы на основании их генетического сходства (парные генетические расстояния d) 
методом многомерного шкалирования (рис. 2). В целом казачьи популяции дистанцированы от кавказских групп, тюрков (в том числе казахов), финноугорских народов, балтов, южных славян и центрально-европейских популяций. Генофонд запорожских, кубанских и донских казаков образует единый южный фрагмент восточнославянского генофонда, что согласуется с историческими сведениями об их происхождении. На картах генетических расстояний (рис. 3) видно, что область наибольшего генетического сходства для этих трёх групп охватывает Украину, южные области европейской части России, Беларусь, Польшу, Словакию (генетические расстояния $\mathrm{d}<0,07)$. При этом, запорожские казаки оказываются более близки к украинским популяциям (рис. 3А), донские - к южнорусским (рис. ЗБ), в то время как область сходства для кубанских казаков (рис. 3В) представляет переходный вариант по сравнению с запорожской и донской группами.

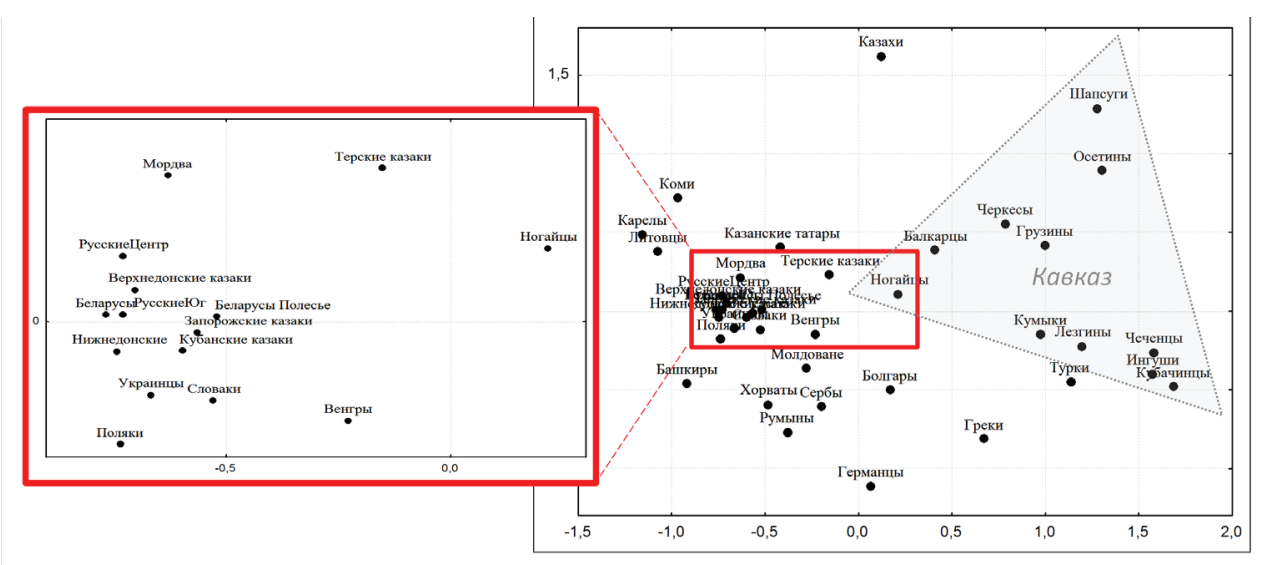

Рис. 2. Сходство популяиий Восточной Европы по гаплогруппам Ү хромосомь

Генофонд терских казаков занимает обособленное положение, несколько дистанцируясь от остальных казачьих групп и тяготея к кавказским тюркоговорящим популяциям - ногайцам и балкарцам (рис. 2). Такое сближение обусловлено резко повышенными частотами «кавказских» гаплогрупп в генофонде терских казаков (рис. 1), что указывает на ассимиляцию терским казачеством мужского коренного населения Северного Кавказа. Об аналогичных результатах сказано в работе [9], содержащей сравнительный анализ генофондов ряда народов Кавказа с народонаселением Европы и Передней Азии - по результатам исследования терские казаки вошли в основной кавказский кластер. Область наибольшего генетического сходства для терских казаков сильно редуцирована по сравнению с остальными группами и ограничивается Приазовьем (рис. 3Г). 

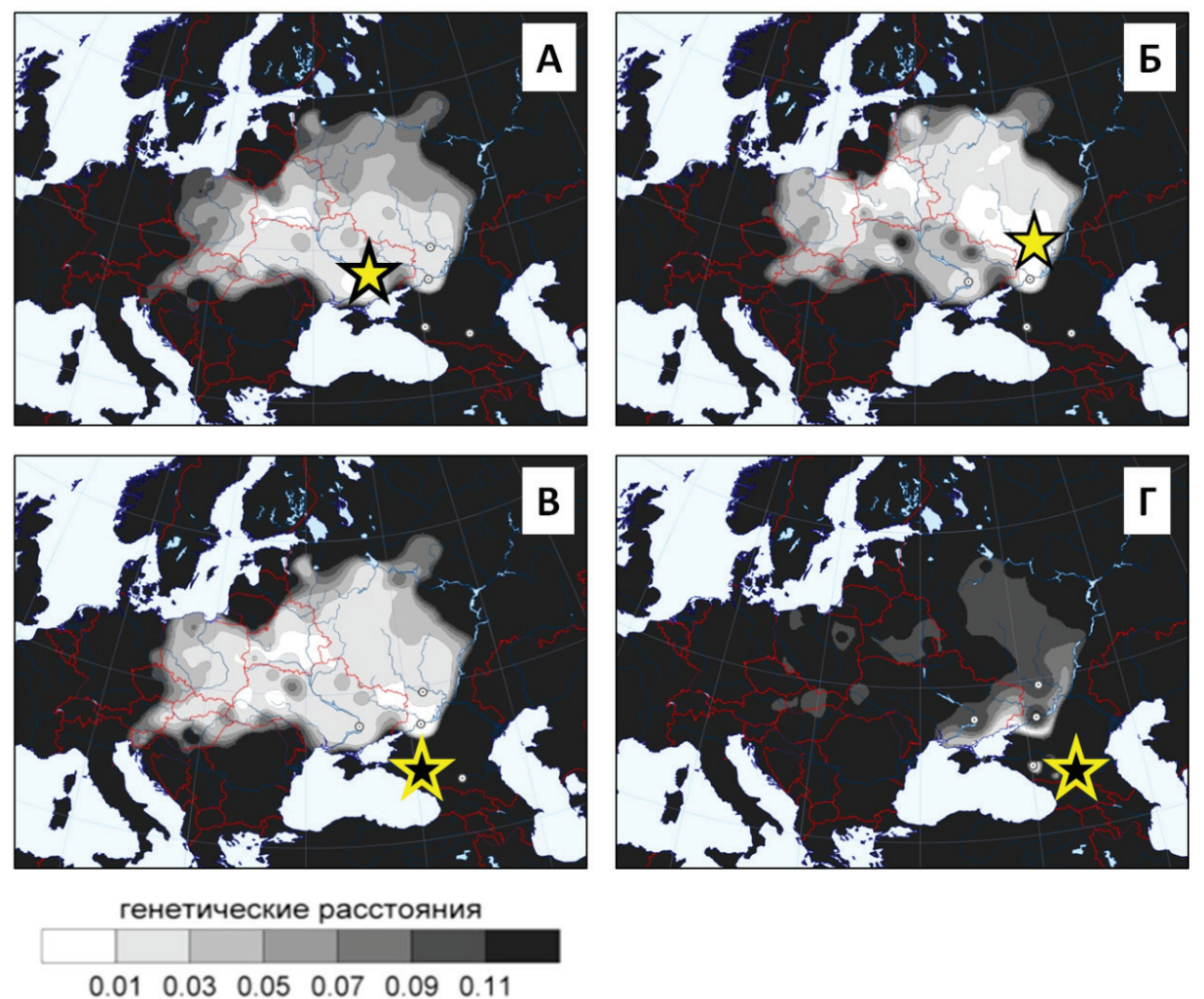

Рис. 3. Карты генетических расстояний от запорожских (А), верхнедонских (Б), кубанских (B), терских (Г) казаков (по данным о частотах гаплогрупп Ү-хромосомы). Реперные популяции обозначены звездочками. Светлые тона соответствуют генетически близким регионам, темные - отдалённым.

\section{Выводы}

1. Y-хромосомный генофонд запорожских, кубанских и донских казаков образует южный фрагмент восточнославянского генофонда. Гипотеза об интенсивном участии кавказского и азиатского населения в генезе украинского и южнорусского казачеств отклоняется низкими частотами или отсутствием в их генофонде кавказских и восточно-евразийских Ү-хромосомных гаплогрупп.

2. Терские казаки дистанцируются от других казачьих групп, смещаясь к некоторым северокавказским популяциям. Спектр и частоты Ү-хромосомных гаплогрупп указывают на ассимиляцию терским казачеством коренного мужского населения Северного Кавказа. 


\section{Благодарности}

Авторы выражают благодарность всем донорам биологических образцов, принявшим участие в исследовании, и персонально атаману Запорожской областной организации международной общественной организации «Международный союз казаков» И. И. Мороховскому и атаману Бердянского казачьего полка А. А. Камаеву за содействие в проведении исследования.

\section{Список использованной литературы}

1. Генофонды абхазо-адыгских народов, грузин и армян в евразийском контексте / И. Э. Теучеж, Э. А. Почешхова, Р. А. Схаляхо и др. // Вестник Московского Университета. Серия ХХІІІ «Антропология». 2013. - № 2. - C. 49-62.

2. Истоки формирования украинского генофонда по данным об Ү-хромосоме / О. М. Утевская, А. Т. Агджоян, Е. В. Балановская и др. // Вісник Харківського університету. - 2013. - Вип. 18 (№1079). - С. 8798.

3. Сходство и различия генофондов украинских и русских популяций Слобожанщины по маркерам Y-хромосомы / О. М. Утевская, А. С. Пшеничнов, Х. Д. Дибирова и др. // Цитология и генетика. - 2015. 49, № 4. - С. 40-50.

4. Тюрки Кавказа: сравнительный анализ генофондов по данным о Ү-хромосоме / Р. А. Схаляхо, Э. А. Почешхова, И. Э. Теучеж и др. // Вестник Московского университета. Серия XXIII «Антропология». 2013. - № 2. - C. 34-49.

5. Genetic Heritage of the Balto-Slavic Speaking Populations: A Synthesis of Autosomal, Mitochondrial and YChromosomal Data / A. Kushniarevich, O. Utevska, M. Chuhryaeva et al. // PLoS One. - 2015. - Sep. 2 , 10(9). - e0135820.

6. Jobling $M$. The human Y chromosome: an evolutionary marker comes of age / M. Jobling, C. Tyler-Smith // Nat. Rev. Genet. - 2003. - 4. - P. 598-612.

7. Koshel S. Geoinformation technologies in genegeography. / Sergey Koshel. - Mod Geogr Cartogr Artic Collect Ed IK Lure VI Kravtsova. - 2012. - P. 158-166.

8. Nei M. Genetic distance between populations // Massatoshi Nei. - Am Nat. - 1972. - 106. - P. $283-292$.

9. Parallel Evolution of Genes and Languages in the Caucasus Region. / O. Balanovsky, Kh. Dibirova, A. Dybo et al. // Mol. Biol. Evol. - 2011. - 28(10). - P. 2905-2920.

10. The genetic legacy of the expansion of Turkic-speaking nomads across Eurasia. / B. Yunusbayev, M. Metspalu, E. Metspalu et al. // PLoS Genet. - 2015. - Apr 21;11(4). - e1005068.

11. The phylogeography of $\mathrm{Y}$ chromosome binary haplotypes and the origins of modern human populations / P. A. Underhill, G.Passarino, A. A. Lin et al. // Ann. Hum. Genet. - 2001. - 65. - P. 43-62.

12. Two sources of the Russian patrilineal heritage in their Eurasian context / O. Balanovsky, S. Rootsi, A. Pshenichnov et al. // Am. J. Hum. Genet. - 2008. - 82(1). - P. 236-250.

13. Y-Chromosome Concortium. A nomenclature system for the tree of human Y-chromosomal binary haplogroups. // Genome Res. - 2002. - 12. - P. 339-348.

Статья поступила в редакцию 22.10.2015 


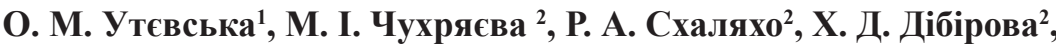
І. Е. Теучеж ${ }^{2}$, А. Т. Агджоян ${ }^{3}$, Л. О. Атраментова ${ }^{1}$, О. В. Балановська ${ }^{2}$, О. П. Балановський ${ }^{3}$

${ }^{1}$ Харківській національний університет імені В. Н. Каразіна, м-н Свободи, 4 , Харків, 61022, Україна

${ }^{2}$ ФГБНУ «Медико-генетичний науковий центр», вул. Москворечье, 1 , Москва, 115478, Росія

${ }^{3}$ Інститут загальної генетики ім. М. І. Вавілова РАН, вул. Губкіна, 3, Москва, 119991, ГСП-1, Росія

\title{
ПОХОДЖЕННЯ ОСНОВНИХ ГРУП КОЗАЦТВА ЗА ДАНИМИ ПРО ПОЛІМОРФІЗМ У ХРОМОСОМИ
}

\begin{abstract}
Резюме
Для прояснення питання про походження козаків на території України та Росії, генофонд основних груп козацтва був вивчений за SNP маркерами Y хромосоми. Кубанські, донські й запорізькі козаки утворюють єдиний південний фрагмент східнослов'янського генофонду. Область найбільшої генетичної схожості для цих трьох груп охоплює Україну, південні області європейської частини Росії, Білорусь, Польщу, Словаччину (генетичні відстані d<0,07). При цьому запорізькі козаки більш подібні до українських популяцій, донські - до південноросійських, кубанські козаки проміжні у порівнянні з запорізькою і донською групами. Найбільш поширеними гаплогрупами Ү-хромосоми серед кубанських, донських й запорізьких козаків $є$ R1a1a1*(M198), I2a (P37.2), R1a1a1g (M458), N1c1 (M178), I1 (M253) i R1b1b2 (M269). Невисокі частоти гаплогруп G i J, що характерні для популяцій Кавказу, а також практична відсутність східноєвразійських гаплогруп С і О відхиляють гіпотезу про активну участь кавказького і степового азіатського населення у генезі цих трьох груп українського та південноросійського козацтва. Генофонд терських козаків займає відособлене положення. Він дистанціюється від інших козачих груп і тяжіє до кавказьких тюркомовних популяцій - ногайців і балкарців. Таке зближення зумовлено різким підвищенням частот «кавказьких» гаплогруп у генофонді терських козаків, що вказує на асиміляцію терським козацтвом чоловічого корінного населення Північного Кавказу.
\end{abstract}

Ключові слова: козаки; SNP-маркери; Y хромосома; гаплогрупи; генетична відстані. 
O. M. Utevska ${ }^{1}$, M. I. Chukhryaeva ${ }^{2}$, R. A. Skhalyakho ${ }^{2}$, Kh. D. Dibirova ${ }^{2}$, I. E. Teuchezh' ${ }^{2}$, A. T. Agdzhoyan ${ }^{3}$, L. A. Atramentova ${ }^{1}$, E. V. Balanovska ${ }^{2}$, O. P. Balanovsky ${ }^{3}$

${ }^{1}$ V. N. Karazin Kharkiv National University, 4, Svobody sq., Kharkiv, 61022, Ukraine

${ }^{2}$ Research Centre for Medical Genetics, 1, Moskvorechie, Moscow, 119991, Russia

${ }^{3}$ Vavilov Institute of General Genetics RAS, 3, Gubkin st., Moscow, 115478, Russia

\title{
GENESIS OF MAJOR COSSACK GROUPS ON THE Y CHROMOSOME DATA
}

\begin{abstract}
The Y-chromosomal polymorphism of the main groups of Cossacks from modern Ukraine and Southern Russia was analyzed to trace their origin and reveal the degree of admixture with neighboring populations. The Kuban Cossacks, Don Cossacks and Dnieper Cossacks form an entire southern part of East-Slavic gene pool. The area of strong genetic affinity for these Cossack groups includes Ukraine, South Russia, Belarus, Poland and Slovakia. Dnieper Cossacks are more similar to the Ukrainian populations, Don Cossacks - to the southern Russian ones, whereas Kuban Cossacks are intermediate between Dnieper and Don Cossack groups. The major haplogroups of Y chromosome in Dnieper, Kuban and Don Cossacks were R1a1a1*(M198), I2a (P37.2), R1a1a1g (M458), N1c1 (M178), I1 (M253), R1b1b2 (M269). At once, the specific for Caucasus region haplogroups $\mathrm{G}$ and $\mathbf{J}$ were minor, as well as East Eurasian haplogroups $\mathrm{C}$ and $\mathrm{O}$, which are wide spread among Asian steppe populations were virtually absent in listed Cossack groups. It allows to reject the hypothesis on extensive incorporation of Caucasus and Asian steppe genetic components in Cossack gene pool. The Terek Cossacks differed significantly from other considered Cossack groups. They have lower frequency of R1a1a1*(M198) and I2a (P37.2) haplogroups, but instead carry high portion of G2a3b1 (P303) and G2a1a (P18) which significant frequencies are specific to Caucasus region. Terek Cossacks reveal some affiliation to Turkic-speaking Nogays and Balkars. The area of genetic affinity for Terek Cossacks lies in narrow region near the Azov Sea. We conclude that main present-day Cossack groups are the part of entire East-Slavic genetic continuity, excepting Terek Cossacks assimilated indigenous Caucasian component.
\end{abstract}

Key words: Cossacks, SNP markers, Y chromosome, haplogroups, Nei distances. 